\title{
Lecturer in the COVID-19 Pandemic Period at 30 Universities in Indonesia
}

\author{
Khurotul Aini ${ }^{1}$, Aisya Kemala ${ }^{2}$ \\ \{khurotulainiunismabekasi@gmail.com ${ }^{1}$, aisyakemala@gmail.com $\left.{ }^{2}\right\}$ \\ Bekasi Islamic Universities, Bekasi, Indonesia ${ }^{12}$
}

\begin{abstract}
The Covid-19 virus changes in the implementation of learning at the university. This study aims to determine the implementation of lectures conducted online in the department of physical education and health. The study uses a survey method. The results showed $100 \%$ they are lecturers in physical education and health faculty, $100 \%$ universities were affected by co- $19.100 \%$ haven't. $70.1 \%$ lecture material was accepted by students and $29.9 \%$ expressed doubt. $89.6 \%$ took the exam online, $10.4 \%$ did'nt. $58.4 \%$ had difficulty doing online assessments and $41.6 \%$ had no. $76.6 \%$ used the Zoom, $51.9 \%$ Google Classroom, 41.6\% Google Meet, 28.6 Edmodo, 1.3\% Teacher's room, 2.6\% Cisco Webex, 2.6\% Ms. Office 365, 1.3\% Google for Education, 14.52\% Whatsapp, 1.3\% Youtube and 2.6\% E-learning University. 73.7\% stated online and $26.3 \%$ said no. $23.4 \%$ have barriers to lecturing online, $63.6 \%$ sometimes and $13 \%$ don't. So online lectures can be held in the current Covid-19 conditions.
\end{abstract}

Keywords: Covid-19, physical education, online learning

\section{Introduction}

This Word document can be used as a template for papers to be published in EAI Core Proceedings. Follow the text for further instructions on text formating, tables, figures, citations and references. The occurrence of corona virus disease (Covid19) resulted in many losses in all fields throughout the world. Of course this requires all parties to cooperate with each other and support activities in various fields to keep going with the adaptation to health protocols recommended by their respective governments around the world. Likewise with the implementation of lectures at the university level. In several universities in the world have carried out health protokolo according to the recommendations of the governments of each country. As Crawford argues that there are universities that adjust government recommendations such as abiding by quarantine for 14 days, keeping minimum distance, turning face-to-face learning into online learning as a result of the Covid-19 outbreak[1]. Line state that coronavirus (COVID-19) the deadly virus that causes respiratory illness and pneumonia[2]. Because the spread of this virus through humans occurs due to close contact with infected people, coughing, sneezing, respiratory droplets and can penetrate the human body (lungs) through inhalation through the nose or mouth[3]. There is currently no evidence to support transmission of COVID-19 associated with food. The COVID-19 virus may survive on surfaces for several hours, but simple disinfectants can kill it[4]. 
Officially the President of Indonesia, Joko Widodo, through a video uploaded by the Secretariat Press, Media and Information Bureau through the account of the Presidential Secretariat on May 15, 2020, on the easing of large-scale social restrictions [5] as one of the strategies to prevent the spread that has been implemented before largescale social restrictions in all regions in Indonesia. Of course this affects the activities of the population in Indonesia. Where many activities are carried out jointly such as activities in schools, campuses, offices, buying and selling in markets and so on, but although this co-19 pandemic is global, the response is still local in nature which is influenced by regional governance and social, economic and culture[6].

The Indonesian state is scattered in the form of islands, demanding that the implementation of the CBDR be supported by the awareness of each individual for the common health interests. In the field of education experienced a pretty drastic change. lectures began to shift from meeting directly in class to being changed to online lectures, where lecturers could deliver lecture material from their respective homes. Favale states Covid-19 this forced people to change their habits and pushed them online services for learning, smart working etc on the internet[7]. Changes in habits that humans do as usual changes to new habits that are more likely to use online meetings, study, school, work and other socialization. Of course this needs to be prepared carefully. The readiness factor to carry out lectures online is the main factor to support this. There are 6 preparations that must be done if the lecture is done online. Bao explained the preparations included: (1) making emergency preparedness plans for unexpected problems; (2) dividing the teaching content into smaller units to help students focus; (3) emphasizing the use of "voice" in teaching; (4) working with teaching assistants and gain online supports from them; (5) strengthening students' active learning ability outside of class and (6) combining online learning and offline self-learning effectively[8]. One other important preparation is to assist in the use of online media that can be done by lecturers to students when conducting lectures online. Lioyd in Perrotta explained the state that mentoring is a key factor in effective online teaching, particularly with regard to fostering student engagement in the e-learning environment[1]. These preparations are important to be done carefully before carrying out lectures online.

Several universities have conducted lectures online, including universities that have major in physical education and health. Universities that have these majors certainly have many obstacles, this is because almost entirely for the Strata 1 level lectures are mostly done in practice in the field by doing physical activities. The following are the results of previous studies with the latest data found by researchers such as Jamaluddin stating that online learning can be used as an experience for prospective teachers[9]. Ginns conveys that there are important internal keys in implementing online learning such as perceptions of learning experiences when carrying out online learning [10]. The online lecture implementation of a lecturer needs to pay attention to important things such as student characteristics, methods / approaches of learning concepts to be conveyed, the stages of student learning and to know students' perceptions of teaching and the quantity and quality of assignments from educators[11]. So that researchers are interested in reviewing further about the implementation of lectures currently being conducted by physical education and health lecturers in Indonesia. 


\section{Methodology}

In this study using descriptive qualitative research methods that are using survey techniques. This technique is carried out to collect data and information from research subjects conducted on 10-13 June 2020 with 77 respondents who work as physical and health education lecturers spread in 30 universities, both private and public in Indonesia. The technique of data collection is done by giving questionnaires to all respondents through the Google Drive Link Drive application. The following are parts of the instruments, among others: (1) respondent profile; (2) the impact of co-19 on agencies; (3) online lectures; (4) online lecture success in the academic process, (5) online lecture barriers; (6) types of applications used for online lectures.

\section{Result} obtained:

Based on the questionnaire collection via google form, the following results are

\subsection{Profile of Respondent}

The results of the collection questionnaire via google form the following results are obtained $100 \%$ a lecturer in physical education

\subsection{The impact of Covid-19 on institutions}

The impact of Covid-19 on the workplace agency received a response of $100 \%$ stating that covid-19 had an impact on the workplace agency. Where the campuses have carried out lecture activities and other academic activities carried out from their respective homes.

\subsection{Online lectures}

In this section the researcher developed the instrument based on the online lectures conducted at 30 universities in the department of physical education and health. The results of the respondents as much as $100 \%$ stated that the lecture was conducted online. This online lecture is a recommendation from the faculty to lecturers in physical and health education referring to the recommendation formally submitted by the government of the Republic of Indonesia. Implementation of lectures online has been carried out in accordance with regular lecture schedules.

\subsection{Distribution of lecture implementation in accordance with the faculty}

The results obtained as much as $100 \%$ of the responses stated that they have carried out the lectures in accordance with the faculty's recommendations. In accordance with the advice of the faculty here is about the weight of the task, meetings, schedules in accordance with the rules set by the faculty. 


\subsection{Distribution of lecture material acceptance to students}

For the implementation of lectures conducted from each home, of course less effective in the range of acceptance of the material, especially for students. In Figure $\mathbf{1}$ it is known that as many as $70.1 \%$ of respondents stated that lecture material was acceptable to students while $29.9 \%$ of responses expressed doubt over the mastery of the material submitted online. This is certainly reasonable if previously students have been accustomed to receiving material directly through face to face in class where in general students will be more concentrated when there are lecturers in the class. But now they are required to be able to adapt to the unusual conditions of conducting online lectures. Likewise, lecturers who are used to face-to-face in class and can explore lectures by listening directly to things that are preventing students from attending lectures, are now a little limited because of online learning. In addition, some courses in the physical education department are mostly done in practice in the field, lecturers are very limited to know the understanding of student material when doing physical activities in the home. This is also caused by the limited facilities and infrastructure that exist in each student's home. So from that lecturers must be able to adjust the types of media they will convey, especially in practicum subjects.

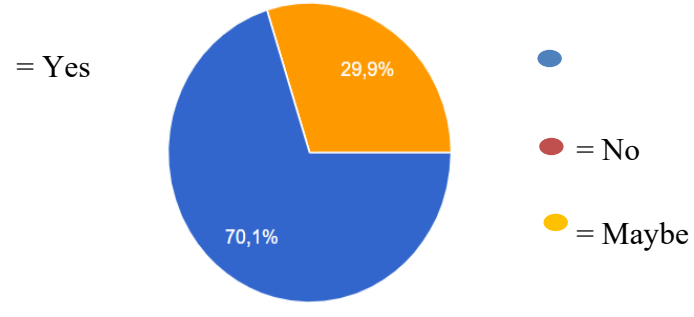

Fig. 1. Distribution of lecture material acceptance to students

\subsection{Distribution of online examination implementation}

For the As an evaluation material for learning including at the university level, of course there is a need for examinations. Both the midterm and final semester exams. In Figure 2 it can be seen that as many as $89.6 \%$ of respondents said they had taken an online test and $10.4 \%$ of respondents said they had not yet taken an online test. Most lecturers are accustomed to conducting tests online both through learning applications and with e-learning that has been provided by their respective universities. But there are some universities that are not accustomed to doing online exams. So there are some lecturers from universities who have not used the online examination technique. 
300

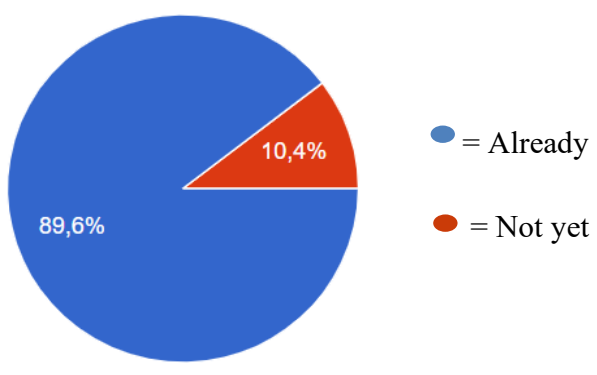

Fig. 2. Distribution of online examination implementation

\subsection{Distribution of online test assessment}

In Figure 3 about the assessment of online examinations shows as many as $41.6 \%$ of respondents have conducted online learning assessment. As many as $58.4 \%$ have not yet conducted online learning assessments. In the distribution of data it is known that more lecturers have not yet conducted online assessments than those who have conducted online assessments. This is triggered by various reasons. The majority of lecturers still choose assessment techniques manually or offline. The habit of assessing students using manual techniques results in lecturers being reluctant to switch. The assessment conducted is not solely about the results of the final exam, but there are many considerations in making an assessment, for example the value of attendance, assignments and the value of exams that have been done, so that lecturers need more time to accumulate the overall value data owned.

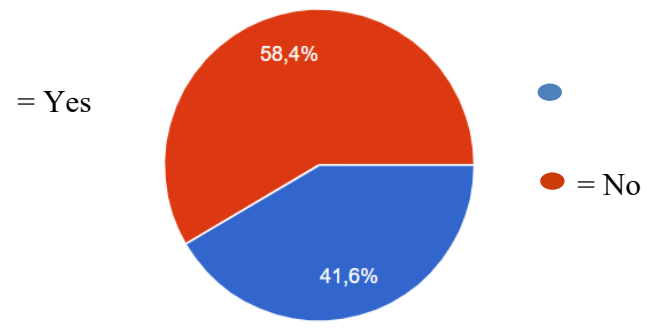

Fig. 3. Distribution of online test assessment

\subsection{Distribution of ease of academic process through online}

Based on Figure 4 regarding the ease of academic activities such as lectures, final assignment guidance is known as many as $73.7 \%$ of respondents stated online simplified the academic process and $26.3 \%$ stated it did not facilitate the academic process. Most of them stated that they will go online for academic conduct on campus. At present many universities have carried out seminar proposals and results exams and even graduations were conducted online during the Covid-19 period. This is done because it does consider the transmission of Covid-19 through face-to-face or on mass or clustered activities. Each university has also provided academic facilities online such 
as to find out the value of studies and study plans that can be accessed via smartphones that can be done anywhere and anytime.

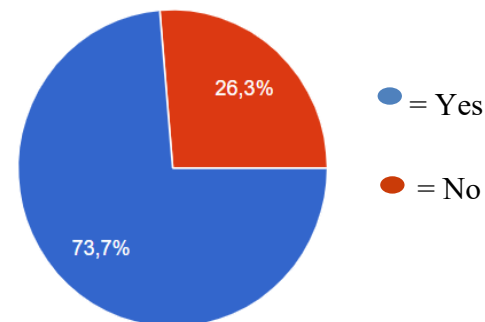

Fig. 4. Distribution of ease of academic process through online

\subsection{Distribution of online lecture barriers}

In Figure 5 it is known that $23.4 \%$ of respondents have online lecture barriers, $63.6 \%$ sometimes and $13 \%$ say they do not have barriers if the learning process is done online. The obstacles presented by lecturers in the instrument section regarding the obstacles to the implementation of lectures online the majority stated that there are obstacles such as student areas scattered in the islands that are difficult to reach by internet signals resulting in smooth communication when lectures are slightly hampered. The limited quota owned by lecturers and students also results in obstacles during learning. The use of applications that require video and voice access requires a large quota if it is not supported by e-learning at each university. Another obstacle when using university e-learning is the limited use of the internet if smartphones and laptops or computers are not close to the campus area. So that the internet network cannot be freely accessed by students and lecturers who carry out lectures in their respective homes. So these obstacles require a review if the lecture is carried out online.

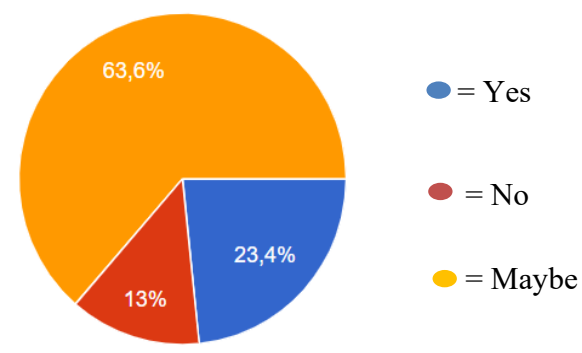

Fig. 5. Distribution of online lecture barriers

\subsection{Applications distribution used for online lectures}

In Figure 6 instruments regarding the types of online learning applications that are used by lecturers when teaching, the results obtained are $76.6 \%$ of respondents using the Zoom application, 51.9\% using Google Classroom, 41.6\% using Google Meet, 28, 6 use Edmodo, 1.3\% use Teacher's room, 2.6\% use Cisco Webex, 2.6\% use 
Ms. Office 365, 1.3\% use Google for Education, 14.52\% use Whatsapp, $1.3 \%$ use Youtube and 2.6\% use E-learning University respectively. There are 4 choices of the most important applications chosen by respondents namely Zoom, Google Classroom, Google Meet and Edmodo which means Zoom is the most important application used by respondents. The use of other applications also supports online learning. The choice of application type used depends on the needs of the lecture itself. The selection of the types of applications used is certainly used by lecturers to transfer knowledge that can be done with work from home. In addition, the selection of application types also depends on the level of ease of use of the application both access and application by lecturers and students. Some universities also have e-learning to facilitate the learning process. We know that it is important for university support to support lecturers and students to adapt to the new learning system. In order to keep the faith conveyed properly, even though they cannot meet in person.

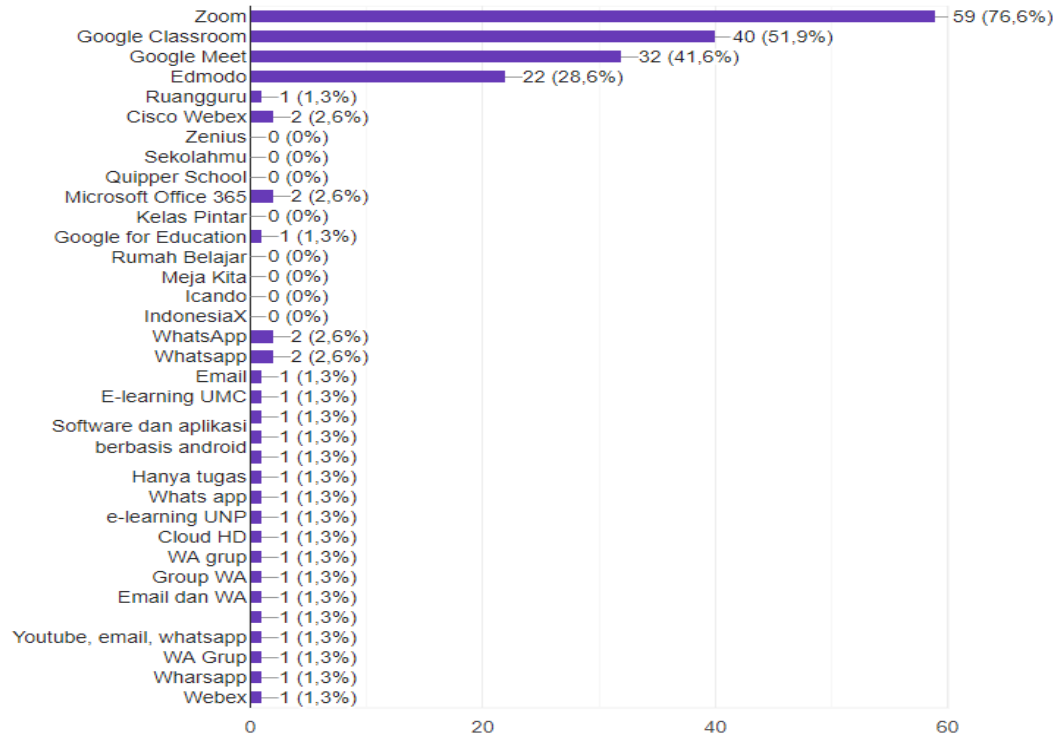

Fig. 6. Application distribution used for online lectures.

\section{Discussion}

The results of the study stated that online learning can be implemented well during the Covid-19 period. At this time the internet has a major role in supporting remote work, e-teaching, online collaboration, games, streaming video etc [7]. We live in a world that is globally connected, in terms of the movement of people, goods, and food, while even within close knit communities[12]. The virus has already had a direct impact on more than 10 million people in the city of Wuhan and has reached other parts of China as well, posing a health threat of unknown magnitude globally[13].

Covid-19 has now become a pandemic in various regions of the world. As a result of this many losses experienced both the countries affected directly and indirectly due to this virus. Major losses such as in economic, social, cultural and educational aspects. 
Of course, these losses must be overcome immediately so that the economy continues to run well. One fundamental loss is a loss in education. The closure of schools and campuses can certainly impede and slow the achievement of targets already set by Governments and/or schools respectively[14]. In the COVID-19 era, the need for innovative solutions to optimize education faster [15]. We all know that education is the foundation of a country's development. The effect of Covid-19 in the field of education resulted in requiring every individual both educators and students to be able to adapt to new activities. Where activities begin to change from virtual to online learning. to carry out online learning at the university level also has many obstacles. These constraints are triggered by human resource factors in the application of the latest knowledge, the limited quota of each individual, as well as the network capacity of each region that is different, especially in Indonesia with widely spread island nations. These obstacles reduce the essence of the learning process or the transfer of knowledge itself if it experiences interference in terms of communication.

In addition to the online learning process, currently universities in Indonesia have also conducted online examinations and exam evaluations, although there are also exam assessments still done manually that is by considering other assessments in addition to exam scores such as attendance, assignments and student activeness during lectures. The online academic implementation process certainly requires lecturers to improve their literacy skills and sources of more updated and actual knowledge so that they can convey to students when learning takes place. The ability to create learning patterns that are tailored to current needs can be a learning material in the future. If currently conducting lectures online as a result of the covid-19 virus it is expected that in the future learning can be blended ie lectures face-to-face combined with lectures online. this is also mentioned in the results of research conducted by Ellis which states that online learning is one of the supporting lectures conducted face to face[16]. The selection of different learning methods will certainly reduce boredom for students and increase student interest in attending lecturer lectures, Jamaluddin also added that the online system can be an additional experience for prospective teachers in the future[9].

In the assessment process, of course, it also needs to be adjusted to the use of lectures online at the university level. The assessment of lectures is expected at this time to have been carefully prepared by the lecturer, so as to facilitate the performance of students and easily access the grades given by the lecturer in the course being taught. Daniel said that teaching should include varied assignments and work that puts COVID-19 in a global and historical context. When constructing curriculum and designing student assessment[17]. Covid-19 requires lecturers to change conventional teaching styles into modern learning while still achieving learning goals without reducing the content and essence of knowledge that will be transferred to students. In the physical education department for Strata 1, more practical hours are needed in the field, lecturers submit practical material online, then students also carry out and develop in their respective homes in accordance with instructions from the lecturer. Weaknesses when practicing at home are limited facilities and infrastructure that are not in accordance with the standards of the university, which results in students not maximizing when practicing independently. Online education is also very dependent on the server computer, smartphone so that there are possibilities that hosts in online learning application users find it difficult to operate or are limited in the number of participants who can follow certain media platforms so the lecturer must be deft to determine other 
plans so that the implementation of lectures continues to be carried out. The lecture activities carried out online certainly have these obstacles usually followed by signal connection problems, quotas. In addition, lecturers are required to be varied when delivering lectures so that students do not experience boredom and passivity when lecturing online. To overcome this we can divide the lecture materials into small parts that can use a shorter duration than traditional learning.

If learning is conventionally supported by body language, facial expressions and voices from lecturers on online learning those things are certainly very limited. So it is important for lecturers to adjust the tempo of speech and convey important things related to the material presented because of the limitations of the signal in each different region. The implementation of online learning must also be supported by teaching resources that are responsive to the development of science and technology. But unfortunately many lecturers in Indonesia, especially for lecturers who are reluctant to switch to online learning, certainly require further assistance, the use of assistants in using the learning media platform is very necessary to fill in the blanks of online learning. Lecturers in online learning lack control in terms of student understanding of the material delivered online, sometimes students lack concentration when learning is done online, so to increase the level of student understanding lecturers prefer to use assignments so students are more active in developing knowledge. To improve student understanding based on the results of research conducted by Chick stated that by providing access to students to freely search for sources of literature from inter-university libraries through online can be used to improve science at this time[18]. To do online learning using a class discussion strategy is very limited because the distribution of communication in online learning platforms is usually very limited. So the depth of the contents of the material if delivered with a discussion is less efficient. Then the lecturer is expected to be able to develop a learning strategy that is suitable for use in the current Covid-19 period. In the research conducted by Ortiz stated that by forming a community of teachers or lecturers can be used as a means of communication and development of teaching methods in the classroom in online learning[19]. New strategies for carrying out lectures online are expected to be developed in an interesting way. It is important for faculty to carry out monitoring, mentoring and professional development of online teaching[20]. So that the implementation of online learning can be easily done by students and lecturers certainly requires the support of campus stockholders.

\section{Conclusion}

The main objective of this research is to find out the implementation and obstacles of lectures in the department of physical education and health in various universities in Indonesia when conducted online in the current Covid-19 mass. The results of this study indicate that with the Covid-19 virus condition lectures can be done online by lecturers to students through the available online learning applications. However online learning has several obstacles during implementation such as the number of Human Resources for operating online learning media platforms is still limited, the territory of Indonesia which is spread over several islands has resulted in unstable networks in certain regions, limited lecturer quota also resulted in learning online is not well done. Online lectures require lecturers to be creative and able to develop their 
abilities, especially in the use of technology for lectures so they can be used as learning strategies in the future. Some applications that have been proven effective are used in online learning, including Zoom, Google Classroom, Schoology, and Edmodo[21]. So it is important to thoroughly prepare thoroughly before carrying out lectures online, although currently universities, especially in the department of physical education and health have carried out lectures online. This is nothing else so that the purpose of online lectures remains to be achieved and is carried out effectively and efficiently.

Acknowledgments Thank you to the members of the writing team who provided input in writing the article. and 45 Bekasi Islamic University which always supports the works of lecturers.

\section{References}

[1] Crawford J, Butler-henderson K, Rudolph J, Malkawi B, Glowatz M, Magni PA, et al. COVID-19: 20 countries' higher education intra-period digital pedagogy responses. J Appl Learn Teach 2020;3.

[2] Canady VA. Mental health groups providing support, education in wake of COVID19. Ment Heal Wkly 2020;30:1-3.

[3] Shereen MA, Khan S, Kazmi A, Bashir N, Siddique R. COVID-19 infection: Origin, transmission, and characteristics of human coronaviruses. J Adv Res 2020;24:91-8.

[4] GUIDANCE FOR COVID-19 PREVENTION AND CONTROL 2020.

[5] Sekretariat Kabinet Republik Indonesia _ Keterangan Pers Presiden Republik Indonesia mengenai Isu Penerapan Pelonggaran Pembatasan Sosial Berskala Besar (PSBB), 15 Mei 2020, di Istana Merdeka, Provinsi DKI Jakarta n.d.

[6] Shaw R, Kim Y, Hua J. Governance, technology and citizen behavior in pandemic: Lessons from COVID-19 in East Asia. Prog Disaster Sci 2020;6:100090.

[7] Favale T, Soro F, Trevisan M, Drago I, Mellia M. Campus traffic and e-Learning during COVID-19 pandemic. Comput Networks 2020;176:107290.

[8] Bao W. COVID-19 and online teaching in higher education: A case study of Peking University. Hum Behav Emerg Technol 2020;2:113-5.

[9] Proyeksi SD. Pembelajaran Daring Masa Pandemik Covid-19 Pada Calon Guru : 2020.

[10] Ginns P, Ellis RA. the student experience of blended learning 2009;40:652-63.

[11] Prosser M, Ramsden P, Trigwell K, Martin E. Dissonance in Experience of Teaching and its Relation to the Quality of Student Learning. Stud High Educ 2003;28:37-48.

[12] Watkins J. Preventing a covid-19 pandemic. BMJ 2020;810:m810.

[13] Chen P, Mao L, Nassis GP, Harmer P, Ainsworth BE, Li F. Coronavirus disease (COVID-19): The need to maintain regular physical activity while taking precautions. J Sport Heal Sci 2020;9:103-4.

[14] Barid M, Wajdi N, Faruq U Al. Education Policy Overcome Coronavirus, A Study of Indonesians 2020;3:96-106.

[15] Almarzooq ZI, Lopes M, Kochar A. Virtual Learning During the COVID-19 Pandemic. J Am Coll Cardiol 2020;75:2635-8.

[16] Ellis RA, Ginns P, Piggott L. E - learning in higher education : some key aspects and their relationship to approaches to study 2009;4360.

[17] Daniel SJ. Education and the COVID-19 pandemic. Prospects 2020

[18] Chick RC, Clifton GT, Peace KM, Propper BW, Hale DF, Alseidi AA, et al. ARTICLE IN PRESS Using Technology to Maintain the Education of Residents During the COVID-19 Pandemic. J Surg Educ 2020. 
[19] Ortiz PA. Teaching in the time of COVID-19. Biochem Mol Biol Educ 2020;48:201201.

[20] Perrotta K, Bohan CH. A Reflective Study of Online Faculty Teaching Experiences in Higher Education Katherine Perrotta, Mercer University, n.d.

[21] Pratiwi EW. Dampak COVID-19 terhadap kegiatan pembelajaran online di sebuah perguruan tinggi kristen di Indonesia. Univ Kristen Satya Wacana 2020;34. 